\title{
Analysis of The Effect Locus of Control and Leadership Style on Auditor Performance with Job Satisfaction as A Mediation (Study at Audit Board of the Republic of Indonesia Representative of East Java Province)
}

Tri Maryanti*, Endah Susilowati

Faculty of Economics and Business, Universitas Pembangunan Nasional “Veteran” Jawa Timur, Surabaya 60294, Indonesia

${ }^{*}$ Corresponding author:

E-mail: limon3yanti@gmail.com

\begin{abstract}
Locus of control is an indicator that affects job satisfaction and performance. The aspects that are assessed on the performance of the Audit Board auditors cannot be separated from the locus of control, leadership style, and job satisfaction. All these aspects are assessed proportionally by giving a more dominant weight to work performance without neglecting the aspects of work behavior. The selection of Audit Board Representative of East Java Province auditors cannot be separated from the locus of control and leadership style to create auditor performance which is mediated by job satisfaction in East Java, both because of internal and external factors. The purpose of this study is to analyze the effect of locus of control on job satisfaction of auditors at Audit Board Representatives of East Java Province, analyze the effect of job satisfaction on auditor performance, analyze the effect of locus of control on auditor performance, analyze the effect of leadership style on auditor performance, analyze the effect of job satisfaction mediates locus of control on auditor performance and analyzes job satisfaction mediates leadership style on auditor performance. This research used quantitative methods, while the sampling technique is based on purposive sampling and data processing use Partial Least Square (PLS) analysis with SMART PLS software. The results show that each variable affects each of the other variables. This research contributes to Audit Board Representatives of East Java Province paying close attention to the locus of control of auditors and considering work management mechanisms that harmonize the relationship between superiors and auditors. Therefore, further research requires more diverse and in-depth interviews, as well as various respondents.
\end{abstract}

Keywords: Locus of control, leadership style, auditor performance, job satisfaction

\section{Introduction}

The success of the implementation of Audit Board duties and authorities in the management and responsibility of state finances is a reflection of the performance of the auditors who are the subject of audit executors. However, many internal and external factors reflect the positive achievements and performance of Audit Board auditors. The case of financial scandals involving government internal auditors at the Audit Board has also become a public discussion which has been able to form negative stereotypes on the performance of Audit Board auditors. This is revealed by the existence of several cases of code of conduct by Audit Board auditors such as offering bribes, gratuities, and money laundering.

\section{How to cite:}

Maryanti, T., \& Susilowati, E. (2021). Analysis of the effect locus of control and leadership style on auditor performance with job satisfaction as a mediation (Study at audit board of the republic of Indonesia representative of East Java Province). $3^{\text {rd }}$ Economics, Business, and Government Challenges 2020. NST Proceedings. pages 61-70. doi: 10.11594/ nstp.2021.1309 
Violation of the code of ethics that involves the credibility, dignity, respect, and image of the Audit Board certainly violates Audit Board RI Regulation Number 4 of 2018 concerning the Audit Board Code of Ethics, although on the other hand the performance of the Audit Board is also measured by compliance with applicable regulations. Therefore, the imposition of sanctions on the Audit Board auditors is a follow-up to the direct supervisor's performance assessment in the form of financial sanctions, verbal and written warnings.

The desire of auditors to gain greater personal benefits or the inability to control unprofessional behavior, assimilation with inappropriate or non-contributing leadership styles, and lack of job satisfaction will have an impact on sub-optimal performance Hasibuan (2016) states that one of the factors affecting employee job satisfaction is the leader attitude in leadership except other factors such as fair and proper remuneration, proper placement according to expertise, atmosphere, and work environment, equipment which supports the implementation of work, the nature of the job is monotonous or not.

In general, the organization uses salary/income as a measure of employee satisfaction, which is expected to drive good performance. In the case of auditors who violate time attendance discipline despite knowing the consequences of deducting performance allowances, it indicates that several factors influence a person and motivates him/her to take an action. The theory of motivation reveals that salary/income is one of the basic needs to support job satisfaction, which should encourage someone to perform well.

Research Neghe et al. (2018) reveals that job satisfaction affects auditor performance. Auditors who do not get job satisfaction will never reach psychological maturity, and in turn, will become frustrated. Research results Guatama and Arfan (2010) reveal that job satisfaction produces a significant positive influence on performance.

Better auditor performance must be following certain standards and timeframes, including First, the quality of work, namely the quality of completing work by working based on all abilities and skills, and knowledge possessed by auditors. Second, the quantity of work, namely the results of work that can be completed with the target that becomes the auditor's job responsibility and the ability to utilize work-supporting facilities and infrastructure. Third, punctuality, namely the timeliness available to complete work.

Performance appraisal at the end of each inspection is carried out in stages by a functional position in the composition of the Audit Duty Letter which contains three aspects of the assessment, namely work objectives, behavioral competence, and technical competence. Meanwhile, the performance appraisal at the end of the year is carried out by the direct supervisor of each employee.

The aspects assessed on the performance of the Audit Board auditors cannot be separated from the locus of control, leadership style, and job satisfaction. As expressed by Amalini et al. (2016) that every individual has beliefs and perceptions of everything that affects him. This belief is called locus of control. Locus of control is described as a person's perspective on an event that can influence a person to be able or unable to control events that occur to him. Locus of control is an indicator that affects job satisfaction and auditor performance. The attitude of an auditor towards the work that is occupied is potentially also influenced by how the auditor's perception of the job.

In addition to the leadership style which is a factor outside the individual, some factors come from the individual and play an important role in influencing one's performance, namely job satisfaction. Handoko (2011) states that job satisfaction is an emotional condition both in a happy and unpleasant state felt by employees in assessing their work.

The results of Fembriani and Budiartha (2016) study of the Audit Board Representative Bali auditor respondents revealed that leadership style did not affect the performance of the Audit Board RI auditors at the Bali Provincial Representatives. This is presumably because no matter how good the leadership style is if it is not supported by hard work and the efforts of the auditors themselves, satisfactory performance will not be achieved. The results of this study are one of the 
writer's strong bases for researching the auditors of Audit Board Representatives of East Java by juxtaposing locus of control as a variable that plays an internal influence on the auditor.

The selection of Audit Board Representative of East Java Province auditors as respondents was motivated by the reason that previous studies had not measured internal and external variables in their influence on the performance of government external auditors by including job satisfaction as mediation. Meanwhile, the election of the Audit Board Representative of East Java Province was based on the type of organization.

\section{Material and Methods}

Research design, sample determination, and analysis technique

This research used quantitative methods. The research design used in this study was intended to examine the effect of locus of control and leadership style on auditor performance by mediating job satisfaction at Audit Board Representatives of East Java Province. The sampling technique is based on purposive sampling, While the statistical analysis used in this study is the validity and reliability test as well as testing the hypotheses compiled in the study. Data processing for the relationship between research variables will use Partial Least Square (PLS) analysis with SMART PLS software.

\section{Results and Discussion}

Results

Overview of respondents

This study involved 105 respondents according to sorting based on several criteria for a total population of 165 people. In this study, the profile of the respondents was divided into several statements in the form of gender, years of service, level of education, and the role of the Functional Examiner.

Table 1. Respondent Demographics

\begin{tabular}{|c|c|c|}
\hline $\begin{array}{c}\text { Profile of Respondents Specifica- } \\
\text { tion }\end{array}$ & Number of people & Percentage \\
\hline \multicolumn{3}{|l|}{ (\%) Gender } \\
\hline Female & 41 & $39 \%$ \\
\hline Male & 46 & 61 \\
\hline \multicolumn{3}{|l|}{ Years of Service } \\
\hline$>10$ years & 83 & $79 \%$ \\
\hline 5-10 year & 22 & $21 \%$ \\
\hline \multicolumn{3}{|l|}{ Education } \\
\hline S1 & 73 & $69.5 \%$ \\
\hline S2 & 32 & $30.5 \%$ \\
\hline \multicolumn{3}{|l|}{ Role of Functional Positions } \\
\hline Intermediate Examiner & 15 & $14.3 \%$ \\
\hline Young Examiner & 63 & $60 \%$ \\
\hline First Examiner & 27 & $25.7 \%$ \\
\hline
\end{tabular}

Source: Prima Data, 2020

\section{Evaluation of PLS model}

To assess the outer model (Measurement Model), there are three criteria, namely convergent validity, discriminant validity, and reliability testing. If the loading factor value is more than 0.5 then the convergent validity is fulfilled, but if the loading factor value is less than 0.5 then the 
construct must be dropped from the analysis (Ghozali, 2013). Discriminant validity is measured by comparing the square root value of Average Variance Extracted (AVE) for each construct with the correlation between other constructs in the model. The AVE value of all variables shows that it is greater than 0.5 or has a p-value smaller than the $5 \%$ significance level (Ghozali, 2013). Composite Reliability can be used to measure the internal consistency of measuring instruments. The determination of whether a measuring instrument is reliable or not is done through the reliability coefficient. The reliability coefficient must be greater than 0.7 (Ghozali, 2013).

Table 2. AVE and reliability test result

\begin{tabular}{llll}
\hline Variable & $\begin{array}{l}\text { Average Variance } \\
\text { Extracted (AVE) }\end{array}$ & \multicolumn{2}{l}{ Reliability Test Results } \\
& Composite & Cronbach,s \\
\hline & Reliability & Alpha & \\
Locus of Control (X1) & 0.685 & 0.951 & 0.942 \\
Leadership Style (X2) & 0.751 & 0.978 & 0.976 \\
Job Satisfaction (Y1) & 0.666 & 0.971 & 0.968 \\
Auditor Satisfac- & 0.661 & 0.971 & 0.968 \\
tion (Y) & & & \\
\hline
\end{tabular}

Source: Primary Data Processed by PLS 3.0, 2020

\section{Structural model (Inner model)}

This measurement tests the influence between variables using R Square (R2) or commonly called the coefficient of determination, to provide the proportion or percentage of the total variation in the dependent variable described by the independent variable. The value of R2 lies between $0-1$, and the fit of the model is said to be better if R2 is getting closer to 1 (Ghozali, 2013).

Table 3. Value of R Square (R2)

\begin{tabular}{cll}
\hline Variable & R Square & R Square Adjusted \\
\hline Job Satisfaction $\left(\mathrm{Y}_{1}\right)$ & 0.943 & 0.942 \\
Auditor Satisfaction $\left(\mathrm{Y}_{1}\right)$ & 0.973 & 0.972 \\
\hline
\end{tabular}

Source: Primary Data Processed by PLS 3.0, 2021

Table 4. Q-Square predictive relevance (Q2)

$$
\begin{array}{ll}
\left(Q^{2}\right)=1-\left(1-R 1^{2}\right)\left(1-R 2^{2}\right) & \left(Q^{2}\right) \\
=1-(1-0.943)(1-0.973) & 0.998461
\end{array}
$$

Source: Primary Data Processed by PLS 3.0, 2020

The description in Table 3 shows that the R-Square (R2) value of job satisfaction is 0.943 , which means that the percentage of the influence of locus of control and leadership style on job satisfaction is $94.3 \%$., while the remaining $5.7 \%$ is explained by other variables not explained in this study. The R-Square (R2) value of the auditor's performance is 0.973 , which means that the percentage of the influence of locus of control, leadership style, and job satisfaction on auditor performance is $97.3 \%$, while the remaining $2.7 \%$ is explained by other variables not explained in this research.

Based on the results of the calculations in table 4, it is known that the value of Q2 is 0.998461 . This means that the large diversity of research data that can be explained by the structural model developed in this study is $99.84 \%$, while the remaining $0.16 \%$ is explained by other variables not explained in this study. Hypothesis Test. The research hypothesis can be accepted if the value of the $t$-count $(t$-statistic) $\geq t$-table at an error rate $(\alpha)$ of $5 \%$, namely 1.96 . The following is the value 
of the path coefficients (original sample estimate) and the value of the t-count (t-statistic) in the inner model.

Table 5. Path coefficients (Direct)

\begin{tabular}{|c|c|c|c|c|c|c|}
\hline $\begin{array}{l}\text { Variable } \\
\text { Influence }\end{array}$ & $\begin{array}{l}\text { Original } \\
\text { Sample (0) }\end{array}$ & $\begin{array}{l}\text { Sample } \\
\text { Mean (M) }\end{array}$ & $\begin{array}{l}\text { Standard } \\
\text { Deviation } \\
\text { (STDEV) } \\
\text { (|O/STDEV|) }\end{array}$ & T Statistics & $\begin{array}{c}P \\
\text { Value }\end{array}$ & Result \\
\hline$\overline{\backslash X 1}$ ? Y1 & 0.472 & 0.473 & 0.046 & 10.187 & 0.000 & Accepted \\
\hline $\mathrm{X} 1$ ? Y2 & 0.256 & 0.279 & 0.108 & 2.368 & 0.018 & Accepted \\
\hline $\mathrm{X} 2$ ? $\mathrm{Y} 1$ & 0.522 & 0.522 & 0.045 & 11.557 & 0.000 & Accepted \\
\hline $\mathrm{X} 2$ ? $\mathrm{Y} 2$ & 0.265 & 0.288 & 0.108 & 2.449 & 0.015 & Accepted \\
\hline Y1 ? Y2 & 0.485 & 0.440 & 0.203 & 2.387 & 0.017 & Accepted \\
\hline
\end{tabular}

Source: Primary Data Processed by PLS 3.0, 2020

Table 6. Path coefficients (Indirect)

\begin{tabular}{|c|c|c|c|c|c|c|}
\hline $\begin{array}{l}\text { Variable } \\
\text { Influence }\end{array}$ & $\begin{array}{l}\text { Original } \\
\text { Sample (0) }\end{array}$ & $\begin{array}{l}\text { Sample } \\
\text { Mean (M) }\end{array}$ & $\begin{array}{l}\text { Standard De- } \\
\text { viation } \\
\text { (STDEV) } \\
\text { (|O/STDEV|) }\end{array}$ & T Statistics & $P$ Value & Result \\
\hline \multicolumn{7}{|l|}{$\mathrm{X}_{1} \rightarrow \mathrm{Y}_{1}$} \\
\hline$X_{1} \rightarrow Y_{2}$ & 0.229 & 0.209 & 0.104 & 2.203 & 0.028 & Accepted \\
\hline \multicolumn{7}{|l|}{$X_{2} \rightarrow Y_{1}$} \\
\hline$X_{2} \rightarrow Y_{2}$ & 0.253 & 0.227 & 0.102 & 2.473 & 0.014 & Accepted \\
\hline$Y_{1} \rightarrow Y_{2}$ & & & & & & \\
\hline
\end{tabular}

Based on the results of table 5, it is known that the path coefficient of the effect of locus of control on job satisfaction is 0.472 with a t-count of 10,187 which is greater than the t-table (1.96) and p-value of $0.000<0.05$. This shows that the locus of control affects the job satisfaction of auditors of Audit Board Representatives of East Java Province. The first hypothesis in this study is accepted.

The path coefficient value of the influence of leadership style on job satisfaction is 0.522 with a t-count of 11.557 which is greater than the t-table (1.96) and the p-value is $0.000<0.05$ so that the second hypothesis in this study is accepted. This shows that leadership style affects job satisfaction. The path coefficient value of the effect of job satisfaction on auditor performance is 0.485 with a t-count of 2.387 which is greater than the $t$-table $(1.96)$ and the $p$-value is $0.017<0.05$. This shows that job satisfaction affects auditor performance so that the third hypothesis in this study is accepted.

The path coefficient value of the effect of locus of control on auditor performance is 0.256 with a t-count of 2.368 which is greater than the t-table (1.96) and p-value is $0.018<0.05$. This shows that locus of control affects the performance of auditors so that the fourth hypothesis in this study is accepted. The path coefficient value of the influence of leadership style on auditor performance is 0.265 with a t-count of 2.449 which is greater than the t-table (1.96) and the pvalue is $0.015<0.05$. This shows that the leadership style affects the performance of auditors so that the fifth hypothesis in this study is accepted.

The path coefficient value of the effect of locus of control on auditor performance through job satisfaction is 0.229 with a t-count of 2.203 which is greater than the t-table (1.96) and the p-value is $0.028<0.05$. This shows that locus of control affects the performance of auditors through job satisfaction so that the sixth hypothesis in this study is accepted. The path coefficient value of the 
influence of leadership style on auditor performance through job satisfaction is 0.253 with a tcount of 2.473 which is greater than the t-table (1.96) and the p-value is $0.014<0.05$. This shows that leadership style affects the performance of auditors through job satisfaction so that the seventh hypothesis in this study is accepted.

\section{Direct effect and indirect effect}

Table 7. Direct and indirect effect

\begin{tabular}{cccc}
\hline Variable & \multicolumn{3}{c}{ Path Diagram Conversion } \\
\hline Influence & Total Effects & Indirect & Total \\
$\mathrm{X} 1 \odot \mathrm{Y} 1$ & 0.472 & & 0.472 \\
$\mathrm{X} 1 \odot \mathrm{Y} 2$ & 0.256 & & 0.256 \\
$\mathrm{X} 2 \odot \mathrm{Y} 1$ & 0.522 & & 0.522 \\
$\mathrm{X} 2 \odot \mathrm{Y} 2$ & 0.265 & & 0.265 \\
$\mathrm{Y} 1 \odot \mathrm{Y} 2$ & 0.485 & $0.472 * 0.485$ & 0.485 \\
$\mathrm{X} 1 \odot \mathrm{Y} 1 \odot \mathrm{Y} 2$ & & $0.522 * 0.485$ & 0.229 \\
$\mathrm{X} 2 \odot \mathrm{Y} 1 \odot \mathrm{Y} 2$ & & & 0.253 \\
\hline
\end{tabular}

Source: Primary Data Processed by PLS 3.0, 2020

The table above shows that the total direct effect of locus of control on auditor performance is 0.256 , while the indirect effect of locus of control on auditor performance through job satisfaction is 0.229 so that the direct effect is greater than the indirect effect. The total direct effect of leadership style on auditor performance is 0.265 , while the indirect effect of leadership style on auditor performance through job satisfaction is 0.253 , so the direct effect is greater than the indirect effect.

The total effect is a combination of direct effects and indirect effects in each variable, while the results of the indirect effect show that there is an indirect effect of locus of control and leadership style on auditor performance through job satisfaction of 0.229 and 0.253 . Based on the indirect effect, using job satisfaction as a mediation shows a smaller effect than the direct effect. The following is the recapitulation of hypothesis testing

Table 8. Hypothesis testing results

\begin{tabular}{llc}
\hline Hypothesis & Result \\
\hline H1 & Locus of control affects job satisfaction & Accepted \\
H2 & Leadership style affects job satisfaction & Accepted \\
H3 & Job satisfaction affects auditor performance & Accepted \\
H4 & Locus of control affects the auditor performance & Accepted \\
H5 & Leadership style affects the auditor's performance & Accepted \\
H6 & Locus of control affects the auditor's performance through job sat- & Accepted \\
& isfaction & \\
H7 & Leadership style affects auditor performance through job satisfac- & Accepted \\
& tion & \\
\hline
\end{tabular}

\section{Discussion}

Locus of control affects job satisfaction

The results showed that the hypothesis was accepted. Locus of Control affects Job Satisfaction. Respondents have the belief that jobs that can be done by others, can also complete well by relying on their abilities and achievements. The opportunity to be recognized as having a role for the organization according to its capabilities and achievements is part of the auditor's job satisfaction benchmarks. Many respondents feel satisfied and proud of the work they are doing at 
this time, both because their current job is following their educational background, abilities, skills, and desires as well as the belief that the work is done plays an important role in the progress of the organization.

When an auditor has an internal locus of control, there will be confident in his ability to complete assignments according to his responsibilities which will determine his success, thus causing job satisfaction. Conversely, if an auditor tends to believe in factors outside of himself as determinants of success (external locus of control), then this belief will reduce job satisfaction due to the belief that no matter how strong his efforts are, there are still factors beyond his control that will determine his success.

The results of this study are in line with Ferdyan's (2017) study which revealed that locus of control affects job satisfaction. The higher the locus of control in an employee, it will increase the perceived job satisfaction. In contrast to the research results of Agustia (2009) which concluded that partially, locus of control did not have a significant effect on job satisfaction, however, locus of control and situational leadership behavior simultaneously influenced auditor job satisfaction.

\section{Leadership style affects job satisfaction}

The hypothesis which states that leadership style affects job satisfaction is accepted. Respondents stated that the leadership style applied at Audit Board Representatives of East Java Province was adjusted to the auditor's maturity level. Several respondents acknowledged that their leadership style is a telling style, which is following the type of auditor with low ability and willingness. The superior applies a leadership style by informing, showing, and giving specific instructions. Superior provides clear and detailed instructions to subordinates in carrying out tasks and jobs, regarding what must be done and completed promptly and on time. It is also recognized that superior also applies a one-way communication pattern to their subordinates. The path-goal theory explains that leadership effectiveness depends on how well the leader can provide guidance, motivation, and support to achieve goals and job satisfaction. The leadership style applied to the Audit Board leads to a type of situational leadership style.

Respondents' answers that revealed the influence of leadership style on job satisfaction are in line with the theory and conclusions of previous studies. As Hersey and Blanchard (2013) argue, leaders must understand the maturity level of their subordinates so that they are not wrong in applying leadership styles. Auditor satisfaction arises from the support of superiors who always provide opportunities to convey ideas or input for the achievement of work programs through good communication channels.

The results of this study are the same as Yanoto (2018) in his research on manufacturing companies which revealed that leadership style has a significant effect on job satisfaction. Fitriany et al. (2011) revealed that in small accounting firms, only consideration leadership style affects auditor satisfaction. In medium KAP, no significant factors are affecting the level of job satisfaction of auditors, and in large accounting firms, consideration and structure leadership styles have a positive effect on auditor job satisfaction. Agustia (2009) also revealed that situational leadership behavior has a significant effect on job satisfaction.

\section{Job satisfaction affects auditor performance}

The answers of auditors from the Audit Board Representative of East Java Province revealed that the third hypothesis, namely Job Satisfaction, affects Auditor Performance. The research results are in line with previous theory and research. Titisari (2014) describes that the willingness of employees to show behavior or roles, in this case, a performance that exceeds the demands of the organization, is determined by employees' perceptions of responsibility and their performance which is determined by job satisfaction.

According to the results of the study, the average respondents felt job satisfaction as expressed through several benchmarks that had a positive influence on auditor performance. This shows the closeness between expectations or things that should be accepted with the reality 
obtained by the respondents. Respondents feel job satisfaction by providing a positive assessment of the suitability of educational background, abilities, skills, and desires with work, the job that is assigned can provide opportunities to make their own decisions, creates freedom and independence, satisfactory work benefits (income) and following the load work and responsibility.

Research by Neghe et al. (2018) with auditor respondents from the Audit Board Representative of North Sulawesi Province revealed that job satisfaction has a positive and significant effect on auditor performance. This shows that auditors with a high level of satisfaction with their work have a positive influence on improving their performance, or in other words, the higher the level of job satisfaction that had been by the auditor, so the higher the increase in the performance. Research by Gautama and Arfan (2010) conducted at the Audit Board Representative of Aceh Province also revealed that Job Satisfaction has a significant effect on Auditor Performance.

\section{Locus of control affects auditor performance}

The hypothesis which states that Locus of Control affects Auditor Performance is accepted. The answers of the respondents indicated that they were satisfied with their abilities, comfortable with the work atmosphere, always involved in organizational development, creating good relationships with colleagues and superiors. Respondents feel able to perform well with personal encouragement and base their success and work performance on themselves. Robbins and Judge (2011) also explain that locus of control is the level where individuals believe that they are determinants of their destiny.

Auditors who have an internal and external locus of control will be affected to achieve good performance. Auditors with an internal locus of control will succeed in achieving good performance with their internal encouragement. On the other hand, auditors with an external locus of control can perform well with strong support from factors outside of themselves.

The results of the assessment of the performance of the Audit Board Representatives of East Java Province are a reflection of the strength of confidence in the optimization of the auditor's ability and the success of external support from both colleagues, superiors, and the work environment in the organization. Both work objectives, behavioral aspects, and technical capabilities fully comprehensively characterize the locus of control. Auditors with an internal locus of control will show good performance appraisal results in connection with the optimal implementation of work targets based on their encouragement. Auditors with an external locus of control tend to show good performance appraisal results when they can optimally create external encouragement such as support from colleagues, superiors, and the environment.

\section{Leadership style affects auditor performance}

The fifth hypothesis which states that Leadership Style affects Auditor Performance is accepted. Respondents felt that the superior leadership style at the Audit Board Representative of East Java Province was able to be a factor affecting the implementation of tasks. The opportunities and conditions created by this leadership style can encourage the auditor to get the best performance in the assignment so that the things that are used as benchmarks for the auditor's performance, both at the end of the assignment and at the end of the year can be assessed with maximum results.

Research by Suhartanti et al. (2016) concludes that leadership style has a significant impact and direction on auditor performance. The results of the research by Fembriani and Budiartha (2016) reveal that leadership style does not affect the performance of the Audit Board auditors as representatives of Bali Province. This is presumably because no matter how good the leadership style is if it is not supported by hard work and the efforts of the auditors themselves, satisfactory performance will not be achieved. Agustia's (2009) research results also reveal that situational leadership behavior does not have a significant effect on auditor performance. 


\section{Locus of control affects auditor performance through job satisfaction}

The research hypothesis which states that Locus of Control affects Auditor Performance through Job Satisfaction is acceptable. Auditors with the locus of control will show good performance appraisal results in connection with the optimal implementation of work targets based on their encouragement. Auditors with these characteristics will show good performance appraisal results when they can optimally create external encouragement such as support from colleagues, superiors, and the environment.

The results showed that job satisfaction was able to mediate auditors to perform well with the locus of control encouragement. An auditor who has a strong locus of control will have the confidence that he is capable of carrying out the assigned task and can contribute to the organization and build good and active relationships with colleagues and superiors. The existence of the strength possessed in the person raises job satisfaction and has an impact on the achievement of good performance.

Respondents' answers indicated that the behavior of the Audit Board Representative of East Java Province auditors was determined by their goals when they did something, influenced by what they thought they would do, what they could do (habits), and the consequences of their behavior, in line with the theory of attitude and behavior developed. The auditors' beliefs and feelings of like or dislike and the consequences that accompany behavior become the rationale for acting and responding to situations in the work environment and organization.

\section{Locus of control affects auditor performance through job satisfaction}

The research hypothesis which states that Leadership Style affects Auditor Performance through Job Satisfaction is acceptable. Subordinates will be affected by the suitability or incompatibility of the superior's leadership style in achieving performance. Respondents revealed that the leadership style currently applied at the Audit Board Representative of East Java Province was able to have a positive influence on creating a sense of satisfaction in auditors.

The opportunity to be objectively noticed and appreciated by superiors is also the reason for the feeling of satisfaction at work. Auditors who feel job satisfaction will be motivated to show their best performance with the belief that their work will be assessed professionally by their superiors and become a consideration for superiors to make considerations or decisions about promotions and opportunities to carry out assignments according to the development of the auditor's ability.

Job satisfaction that arises from a leadership style that creates a conducive work situation can motivate auditors to carry out assignments in line with the direction and orders of their superiors and the work rhythm of the auditors. Development of ideas, initiatives, and ways of working that are free but directed in line with organizational goals and supervision of superiors will bring out optimal work results to have an impact on good performance appraisal as well. Agustia (2009) reveals that partially, locus of control does not have a significant effect on job satisfaction and there is an indirect influence between situational leadership behavior on auditor performance through job satisfaction.

\section{Conclusion}

1. Locus of control plays a role in influencing job satisfaction of auditors of Audit Board Representatives of East Java Province;

2. Leadership style plays a role in influencing job satisfaction of auditors of Audit Board Representatives of East Java Province;

3. Job satisfaction plays a role in influencing the auditor performance of Audit Board Representative of East Java Province;

4. Locus of control plays a role in influencing the auditor performance of Audit Board Representative of East Java Province auditors;

5. Leadership style plays a role in influencing the auditor performance of Audit Board Representatives of East Java Province; 
6. Job satisfaction mediates the relationship between locus of control and auditor performance of Audit Board Representatives of East Java Province; and

7. Leadership style mediates the relationship between locus of control and auditor performance of Audit Board Representatives of East Java Province.

\section{References}

Agustia, D. (2009). Pengaruh locus of control dan perilaku kepemimpinan situasional terhadap prestasi kerja auditor dengan kepuasan kerja sebagai variabel intervening. EKUITAS Akreditasi, 110, 1-22.

Amalini, H., Musadieq, M., \& Afrianty, T. (2016). Pengaruh locus of control terhadap kepuasan kerja dan kinerja (Studi pada karyawan perusahaan daerah air minum (PDAM) kota Malang). Jurnal Administrasi Bisnis S1 Universitas Brawijaya, 35(1), 68-77.

Fembriani, A., \& Budiartha, I. (2016). Faktor-faktor yang memengaruhi kinerja auditor BPK RI Perwakilan Provinsi Bali. E-Jurnal Akuntansi, 16(1), 1-17.

Ferdyan, F. (2017). Pengaruh komitmen profesional, komitmen organisasional, motivasi kerja dan locus of control terhadap kepuasan kerja auditor. Media Riset Akuntansi, Auditing dan Informasi, 14(2), 75. https://doi.org/10.25105/mraai.v14i2.2052.

Fitriany, F., Gani, L., Siregar, S. V., Marganingsih, A., \& Anggraita, V. (2011). Analisis faktor yang mempengaruhi kepuasan kerja auditor dan hubungannya dengan kinerja dan keinginan berpindah kerja auditor. Jurnal Akuntansi dan Keuangan Indonesia, 8(2), 171-196. https://doi.org/10.21002/jaki.2011.11

Ghozali. (2013). Structural equation modeling metode alternatif dengan Partial Least Square (PLS), Semarang: Undip.

Guatama, S. I., \& Arfan, M. (2010). Pengaruh kepuasan kerja, profesionalisme, dan penerapan teknologi informasi terhadap kinerja auditor. Jurnal Telaah \& Riset Akuntansi, 3(2),195-205.

Handoko, T. H. (2011). Manajemen personalia dan sumber daya manusia, Yogyakarta: BPFE.

Hasibuan. (2016). Manajemen sumber daya manusia. Edisi Kesembilan, Jakarta: PT. Gunung Agung.

Hersey, P., \& Kenneth. H. B. (2013). Manajemen perilaku organisasi: Pendayungan sumber daya manusia, Terjemahan Agus Dharma, Erlangga, Jakarta.

Neghe, I., Sondakh, J., \& Kalalo, M. (2018). Pengaruh motivasi intrinsik, kompetensi auditor dan kepuasan kerja terhadap kinerja auditor eksternal (Survei pada auditor Bpk-Ri Perwakilan Provinsi Sulawesi Utara). Going Concern: Jurnal Riset Akuntansi, 13(02), 390-401. https://doi.org/10.32400/gc.13.02.19631.2018.

Robbins \& Judge. (2011). Perilaku organisasi. Prentice Hall: Organizational Behavior.

Suhartanti, Purnamasari, \& Gunawan. (2016). Pengaruh struktur audit, gaya kepemimpinan, dan konflik peran terhadap kinerja auditor. Prosiding Akuntansi, 2(2), 1-5.

Titisari, P. (2014). Peranan Organizational Citizenship Behavior (OCB) dalam meningkatkan kinerja karyawan. Jakarta: Mitra Wacana Media.

Yanoto, A. (2018). Pengaruh gaya kepemimpinan terhadap kepuasan kerja melalui motivasi dan kinerja karyawan PT. Nutrifood Indonesia di Surabaya. Jurnal Agora, 6(1), 1-10. 